\title{
A „100 éves a hazai haditechnikai kutatás- fejlesztés" és az Innovation Methodologies for Defence Challenges konferenciák
}

$\Lambda$ mána március első napjaiban megtartott alábbi két tudományos konferencia szorosan kapcsolódott a magyar katonai kutatás-fejlesztés 100 éves évfordulójához.

„100 éves a hazai haditechnikai kutatás-fejlesztés” címmel rendeztek konferenciát és kiállítást március 2-án Budapesten, a HM Hadtörténeti Intézet és Múzeum (HM HIM) Márványtermében. Az MH Modernizációs Intézet, valamint a HM HIM közös rendezvényén Maróth Gáspár, a nemzeti védelmi ipari és védelmi célú fejlesztésekért, valamint a haderő-modernizáció irányításáért felelős kormánybiztos elmondta: bizakodásra ad okot, hogy az elmúlt időszakban sikerült felszínre hozni azokat a pozitív energiákat a Magyar Honvédségben, amelyeknek köszönhetően ismét lehetővé válik haditechnikai kutatások és fejlesztések végrehajtása. „Az egyik fő üzenet, hogy nincs ipari kutatás-fejlesztés haditechnikai kutatás-fejlesztés nélkül. Ma mindenhol a

1. ábra. Dr. Maróth Gáspár a nemzeti védelmi ipari és védelmi célú fejlesztésekért, valamint a haderő-modernizáció koordinálásáért felelős kormánybiztos a 100 éves a hazai haditechnikai kutatás-fejlesztés címü konferencián (Fotó: honvedelem.hu/Tóth László)

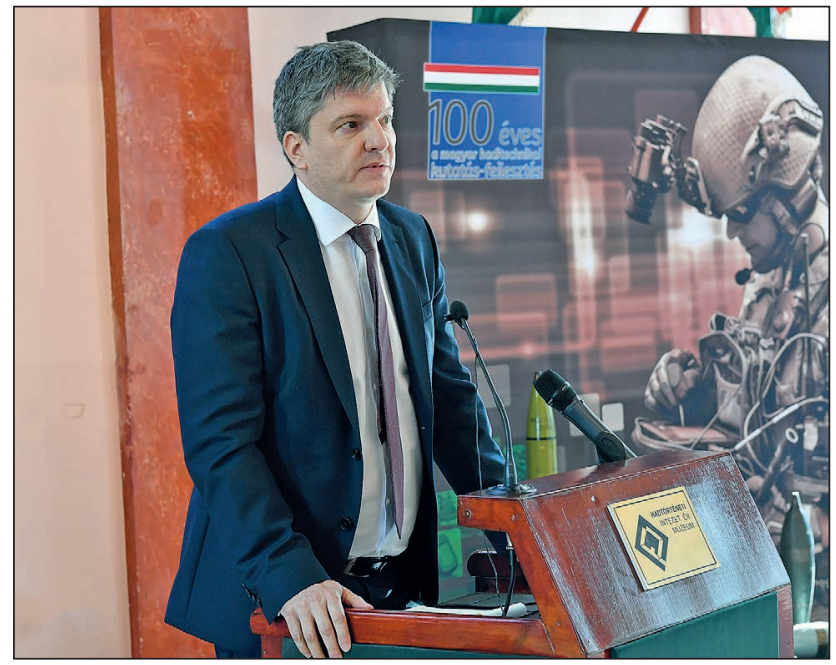

ÖSSZEFOGLALÁS: „100 éves a hazai haditechnikai kutatás-fejlesztés” címmel rendeztek konferenciát és kiállítást 2020. március 2-án Budapesten, a HM Hadtörténeti Intézet és Múzeumban. A Magyar Honvédség Modernizációs Intézet és a Nemzeti Közszolgálati Egyetem közös szervezésében március 3-4-én került megrendezésre az „Innovation Methodologies for Defence Challenges" angol nyelvű nemzetközi konferencia. A rendezvény a magyar katonai kutatás-fejlesztés 100 éves évfordulója alkalmából szervezett rendezvénysorozat részét képezte.

KULCSSZAVAK: design thinking, haditechnikai kutatás-fejlesztés, HM HIM, MH MI, NKE

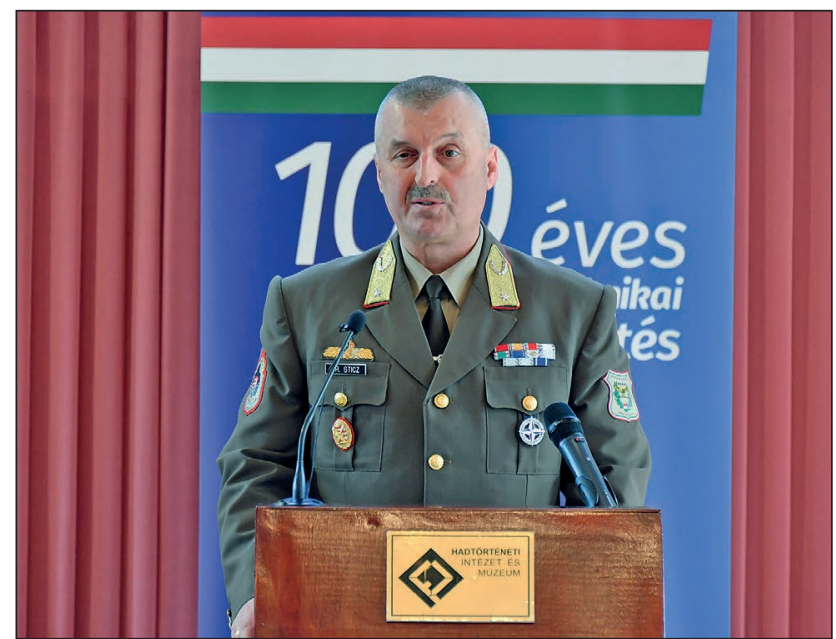

2. ábra. A rendezvényen dr. Sticz László dandártábornok, a Magyar Honvédség Parancsnoksága Haderőtervezési Csoportfőnökség csoportfőnöke köszöntötte a résztvevőket (Fotó: honvedelem.hu/Tóth László)

világban a haditechnika az ék a kutatás-fejlesztésben, oda allokálódnak azok a források, amelyek a leginnovatívabb fejlesztéseket hozzák az ipar területére. Ez azért fontos, mert vissza kell hoznunk a Magyar Honvédséget és a hadtudományokat a Magyar Tudományos Akadémia körein belülre" - hangsúlyozta Maróth Gáspár, hozzátéve: a haditechnikai kutatás-fejlesztés nemcsak a Magyar Honvédség sajátja lesz, hanem markánsan nyitni kell a civilek felé és meg kell tudni szólítani azokat a kutatókat, akik a haderővel együttműködve tudnak ezekben a programokban részt venni. Ha nincs komoly megrendelés, akkor nem is lesz kutatás-fejlesztés. A változásokban kulcsszerepe van a Zrínyi 2026 Honvédelmi és Haderőfejlesztési Programnak, amely nemcsak az irányokat szabja meg, hanem mint megrendelő is fellép a továbbiakban - tette hozzá végezetül a kormánybiztos. A rendezvényen - dr. Sticz László dandártábornok, a Magyar Honvédség Parancsnoksága Haderőtervezési Csoportfőnökség csoportfőnöke köszöntőjét követően - az érdeklődők előadásokat hallhattak a haditech-

ABSTRACT: A conference and exhibition entitled "100 Years of Hungarian Military Technology Research and Development" was organized on March 2 2020, at the HM Military History Institute and Museum in Budapest. An international conference in English "Innovation Methodologies for Defence Challenges" was organized on March 3-4 by the HDF Institute for Modernization and the National University of Public Service. The event was part of a series of events organized on the occasion of the 100th anniversary of Hungarian military research and development.

KEY WORDS: design thinking, military technological research and development, HM HIM, MH MI, NKE 


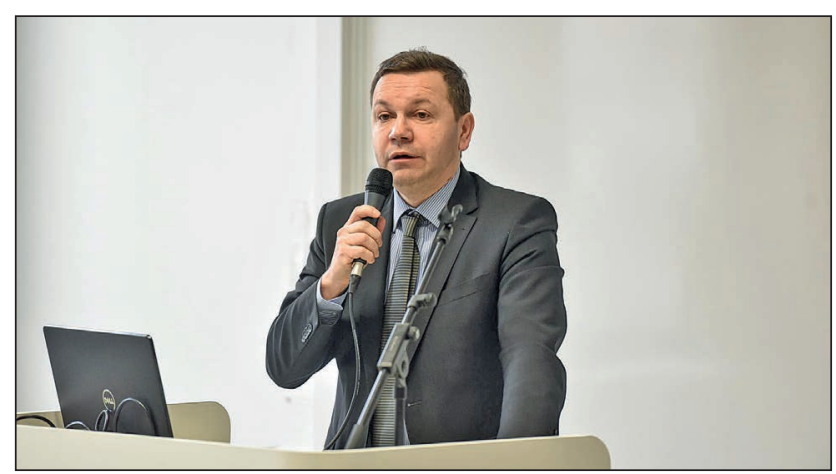

3. ábra. Dr. Kis Norbert, az NKE fejlesztési rektorhelyettese az Innovation Methodologies for Defence Challenges nemzetközi konferencián (Fotó: Szilágyi Dénes)

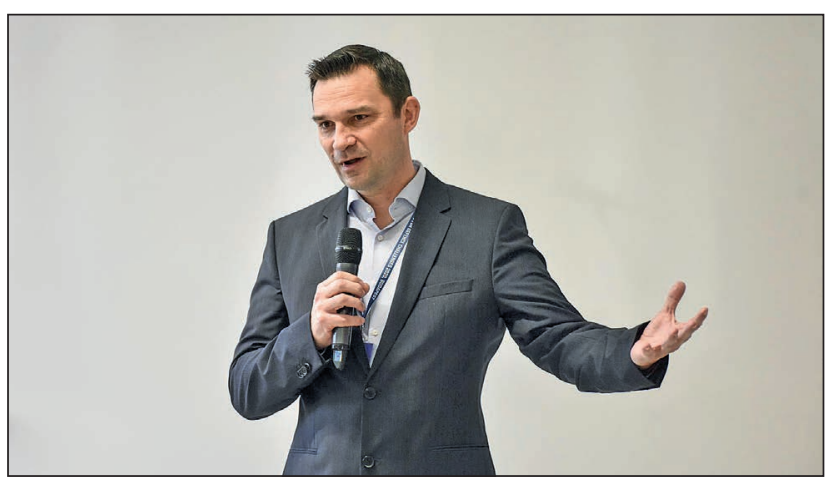

4. ábra. Dr. Porkoláb Imre ezredes, a Nemzeti Fegyverzeti Igazgató kutatás-fejlesztésért és innovációért felelős helyettese - az angol nyelvú nemzetközi konferencia egyik szervezője - a rendezvény első napján a workshop moderátoraként vezette a beszélgetéseket (Fotó: Szilágyi Dénes)

nikai kutatás-fejlesztés múltjáról, jelenéről, a jövő legfontosabb irányelveiről, valamint a Magyar Honvédségen belüli multidiszciplináris kérdésekről.

A Magyar Honvédség Modernizációs Intézet és a Nemzeti Közszolgálati Egyetem 2020 március 3-4-én megtartott, közös Innovation Methodologies for Defence Challenges című nemzetközi konferenciáiának célja az volt, hogy bemutassa az ún. design thinking (kreatív gondolkodás) módszertanát, és annak alkalmazhatóságát a nemzetközi és hazai védelmi problémák megoldásában. A konferencián részt vett és bevezető előadást tartott Németh Gergely, a Honvédelmi Minisztérium védelempolitikáért felelős helyettes államtitkára.

Dr. Kis Norbert, az NKE fejlesztési rektorhelyettese megnyitójában a design thinking és a konferencia aktualitása kapcsán kiemelte, hogy a Nemzeti Közszolgálati Egyetem létrehozása és működésének eszméje is ehhez igazodik: az átfogó megközelítést alkalmazva vonták egy ernyő alá a különböző hivatásrendeket és államigazgatási szakokat. A NKE fejlesztési rektorhelyettese a program jelentősége kapcsán kiemelte: az intézmény is annak szellemében jött létre, hogy a civil szférának lehetősége legyen tanulni a katonáktól és a katonai tudományokból, felhasználva azokat az államigazgatás több területén. Véleménye szerint Magyarországon ennek hosszú múltra visszatekintő hagyománya van, ugyanis két évszázaddal ezelőtt azért hozták létre a Katonai Akadémiát, hogy ott a (katonai) tudományok és a tapasztalatok találkozhassanak egymással.

Ben Zweibelson, az amerikai Joint Special Operations Egyetem oktatója International Military Design Movement (Nemzetközi katonai tervezési mozgalom) című interaktív előadásával világította meg a „design” fogalom sokszínűségét. Előadásában kitért a tervezés nehézségeire, amelyekre megoldást kínálhat - a helyesen alkalmazott - „design thinking", majd hangsúlyozta a tervezés alapú és a design alapú szemléletmódok összekapcsolásának jelentőségét. Zweibelson a vezetői képességek és tulajdonságok sokféleségén át bemutatta, hogy a régi szokások lerombolásával (megváltoztatásával) lehet újat alkotni.

Brian „Ponch” Rivera The Design of Flow: Blending Innovation Methodologies from the Military, Business, and Academia to create the Next Generation Design System (A Flow tervezése: A katonai, az üzleti, és a tudományos szféra innovációs módszertanainak ötvözése az új generációs tervezési rendszer megalkotása érdekében) című előadásában a kérdések különböző perspektívákból történő vizsgálatának fontosságáról beszélt, külön kiemelve két módszertan, a David Snowden professzor által megalkotott helyzetértékelési módszertant (Cynefin), valamint a John Boyd által megalkotott Megfigyelés-TudatosításDöntés-Cselekvés (OODA loop) szemléletmódot.

Jobbágy Zoltán ezredes a probléma és a megoldás közötti kapcsolat megteremtéséről szólt, és történelmi példákon keresztül vázolta a háború fogalmának definiálási nehézségeit. A Nemzeti Közszolgálati Egyetem, Hadtudományi és Honvédtisztképző Kar nemzetközi dékánhelyettese a „véletlent” és a „kiszámíthatatlanságot” folyamatosan jelenlévő komponensként jellemezte a háborúk során, állítását Clausewitz háborúról alkotott nézeteivel támasztotta alá. Hozzátette azt is, hogy a design thinking nem egy új találmány, régóta benne van a történelemben, csak a megfogalmazás új. Szükség van a design thinking-re, mert az analitikus gondolkodás önmagában nem elég - mondta az egyetemi docens, hangsúlyozva a metaforák szerepét a könnyebb érthetőség érdekében. Véleménye szerint a design thinkingnek arról kell szólnia, hogy a „dobozon kívül” kell elkezdeni gondolkodni, ezáltal jobban megérteni és megértetni a problémák lényegét. Bár e különleges gondolkodási mód kapcsán ma sincs teljes egyetértés a szakirodalomban, az alapvetések azonban nem változtak az évszázadok során: a háború fogalmának tartalma folyamatosan fejlődik, a clausewitzi alapvetésekre rárakódtak a modern világ technikai és gondolkodásbeli újdonságai, sajátosságai. A gondolkodás komplexebbé vált, a kérdés viszont több száz éve ugyanaz maradt: hogyan lehet felkészülni a jövő háborújára.

A Nemzeti Közszolgálati Egyetemen rendezett kétnapos konferencia a jövő háborújának kutatásához kíván támpontot adni. A konferencia sikeresen mutatta be a valós védelmi jellegű problémák megoldásának módszereit a design thinking módszertanával.

(Összeállította dr. Hegedüs Ernö)

\section{ForRÁsOK}

Zavodnyik Blanka. „Elmélet alapú gyakorlat, gyakorlat alapú elméletek" hhk.uni-nke.hu Elérés: 2020. 07. 07. https://hhk.uni-nke.hu/hirek/2020/03/04/elmelet-alapugyakorlat-gyakorlat-alapu-elmeletek;

Antal Ferenc. Középpontban a hazai haditechnikai kutatás-fejlesztés. Honvédelem.hu Elérés: 2020. 07. 07. https://honvedelem.hu/cikk/kozeppontban-a-hazaihaditechnikai-kutatas-fejlesztes/;

„A haditechnika az ék a kutatás fejlesztésében” Magyar Honvédség Youtube-csatornája. Elérés: 2020. 07. 07. https://www.youtube.com/watch?v=HNesXvbx984. 